\title{
キャニスターに採取された環境大気中化学物質の 保存安定性の検討
}

\author{
長谷川敦子 \\ 神奈川県環境科学センター（テ 254-0014 神奈川県平塚市四之宮1-3-39） \\ [平成12年12月26日受理］

\section{Examination of Storage Stability of Chemical Substances in Atmosphere Sampling in the Canister}

\author{
Atsuko HASEGAWA \\ Kanagawa Environmental Research Center \\ (1-3-39 Shinomiya, Hiratsuka, Kanagawa 254-0014)
}

[Received December 26, 2000]

\begin{abstract}
Summary
In this study, the storage capability of canister for air sampling was evaluated. Sixty-four volatile organic compounds (VOCs) were spiked into ambient air sample to be $0.4 \sim 2 \mathrm{ppbv}$ in canister in order to examine storage stability, and $43 \mathrm{VOCs}$ found from ambient air sample, minimum concentration was $0.002 \mathrm{ppbv}$, were examined storage stability in the canister. After about a month's storage, 28 of them were successfully recovered. Very volatile organic compounds such as chlorofluorocarbons were also stable over a month. Some polar compounds such as acrylonitrile and 1,3-butadiene were not so stable as non-polar VOCs. Acrylonitrile of ppbv level in concentration were stable or decreased gradually during the storage, and that of quite lower level in concentration was increased under the same condition. Persistence of aldehydes and its increase in both Silico- and SUMMA-canisters, even cleaned, were observed during storage. Similar phenomenon, though its magnitude was very low, was observed about acrylonitrile. These can be explained as residual polar compounds or their decomposition products which still remained in the cleaned canister, gradually shifted from innersurface of the canister to the gas phase. 1,3-Butadiene was also decreased under the same storage condition. The Japan Environment Agency has authorized the same canister method as evaluated on this study, and throughout Japan, acrylonitrile and 1,3-butadiene have been measured with 7 other prior hazardous compounds that were stable over a month in the canister. If the storage is over a long period, air concentrations of acrylonitrile may be overestimated and that of 1,3-butadiene may be underestimated.
\end{abstract}

Key words: canister, GC/MS, atmosphere, acrylonitrile 


\section{1.はじめに}

1996年 5 月に大気污染防止法の一部改正が行われた。 有害大気污染物質のプライオリティリストに 234 種の化 学物質が載せられている。そのなかでも優先取組物質と して環境基準の定められたベンゼンなど 22 物質があげら れている。キャニスターを用いた大気中の揮発性有機化 合物（VOCs）の測定は優先取組物質中 9 物質の測定法 として「有害大気污染物質測定方法マニュアル」」に採用 されており，環境モニタリングが1997年に始まったのを 機にキャニスター-GC/MS は急速に普及した。キャニス ター-GC/MS と従来の吸着剂捕集による環境大気中化学 物質の測定結果を比較しての性能評価 ${ }^{2-4)}$, 加圧採取法と 減圧採取法の比較 よい測定を行うための様々な検討がなされている旾)。

キャニスターは真空にしたステンレス容器に試料大気 を吸引するシンプルな採取法であり, 吸着剤による捕集 のように対象物質が破過する問題や, 吸着剂からの脱着 過程で対象物質が変質する可能性が少ないため多成分の 一斉分析に適している。また減圧採取法では電源など動 力が不要である。装置や機材が高価であることや, キャ ニスターの洗浄, 減圧といった試料採取準備にかかる操 作が煩雑であること, 一度に分析できる試料大気量が一 般に数 $100 \mathrm{~m} \ell$ であことから比較的定量限界が高いと いった短所もあるが, キャニスターは吸着捕集が困難な ごく低沸点の物質に対して極めて有効な試料採取法である。 キャニスターで環境大気中化学物質の測定を行うに は, キャニスター内での化学物質の挙動を把握すること が重要である。キャニスター内での各種化学物質の安定 性などを検討した例は多いが，そのほとんどは環境大気 中よりもはるかに高い濃度の標準ガスを用いた検討や比 較的短期間の保存安定性で6.9-13)，実際に採取したごく低 濃度の環境大気中化学物質の長期にわたる挙動を検討し た例はみあたらない。しかし平成12年 8 月 24 日に環境庁 大気規制課から発表された「平成11年度地方公共団体等 における有害大気污染物質モニタリング調査結果につい て」によると, 全国の300を超える地点で3000～4000検 体を測定した結果, VOCs の平均濃度はベンゼン： $2.5 \mu \mathrm{g} / \mathrm{m}^{3}$ (0.78ppbv), トリクロロエチレン $: 1.8 \mu \mathrm{g} / \mathrm{m}^{3}$ (0.33ppbv)，テトラクロロエチレン : $0.77 \mu \mathrm{g} / \mathrm{m}^{3}(0.11$ $\mathrm{ppbv})$, アクリロニトリル :0.17 $\mu \mathrm{g} / \mathrm{m}^{3}$ (0.08ppbv), 塩 化ビニルモノマー: $0.17 \mu \mathrm{g} / \mathrm{m}^{3} \quad(0.07 \mathrm{ppbv})$, クロロホル 厶: $0.34 \mu \mathrm{g} / \mathrm{m}^{3}$ (0.07ppbv), 1,2-ジクロロエタン: $0.16 \mu \mathrm{g} / \mathrm{m}^{3}$ (0.04ppbv), ジクロロメタン: $2.8 \mu \mathrm{g} / \mathrm{m}^{3}$ (0.79ppbv)，1,3-ブタジエン: $0.32 \mu \mathrm{g} / \mathrm{m}^{3} \quad(0.14 \mathrm{ppbv})$ で $1 \mathrm{ppbv}$ を超えた物質は一つもなく, $1 \mathrm{ppbv}$ 以下の低濃 度試料の挙動を把握する必要がある。また現在実施され ている環境モニタリング調査では, 効率的な分析のため
に試料の保存期間が長くなることも多いと思われる。 著者はキャニスター-GC/MSによる環境モニタリング に携わるあいだに，高濃度の標準ガスでは良好だった試 料の保存安定性が, 低濃度の実試料では安定でなかった り, 同じ条件で保存安定性を試験しても試料採取日に よって違う結果が得られたり，キャニスター内で特定の 物質の濃度が上昇する例 ${ }^{(4)}$ を経験して, 高濃度の標準ガ スで検討しただけでは環境大気中化学物質の測定法とし て問題が残ることがわかった。環境の実試料や実試料に 添加した標準試料でキャニスター内の化学物質濃度の变 動を追跡してきた結果, より精度の高い分析のために必 要な知見が得られたので報告する。

\section{2. 実 験}

\section{1 試料採取場所及び時期}

試料採取場所は神奈川県平塚市（神奈川県環境科学セン ター), 試料採取時期は1997年12月から2000年11月である。

\section{2 キャニスター}

キャニスター内表面を溶融シリカ処理したSilico 缶 (Restek 社製)，ニッケルクロム酸化被膜処理したSUMMA 缶 (SIS 社製, SIBATA 社製) の 3 社 2 種類のキャニス ターを用いた。容量はいずれも $6 \ell$ である。試料採取に 用いるキャニスターは洗浄して真空にした後, 超純水 100 $\mu \ell$ を添加して採取まで保存した。キャニスターのよう な金属容器の内表面に水の膜を形成させることによって 低濃度四塩化炭素の保存性が高まるという報告 ${ }^{15)}$ があ り, キャニスター導入当初メーカーの使用マニュアルに も指示されていたので超純水添加を行っていた。その後 キャニスター内面処理技術の向上により低湿度での保存 安定性が向上したとの報告 ${ }^{10}$ があり，著者の実験でも極 性物質のブランクが上昇しやすくなることが確認された ので，2000年 4 月からは超純水の添加は行わなかった。

\section{3 標準ガス}

標準ガスは高千穂化学工業製 TO-14（44種混合, 各 $1 \mathrm{ppm}$ (窒素バランス), 高千穂化学工業製水素化フロン 7 種混合 (各 $1 \mathrm{ppm} /$ 窒素バランス), 住友精化製 VOCs51種混合 (HAPs-J44+水素化フロン 7 種, 各 1 $\mathrm{ppm} /$ 窒素バランス), 住友精化製酸化エチレン (10ppm/ 窒素バランス), 内部標準ガスは大陽東洋酸素製トルエ ン $d 8$ ( $1 \mathrm{ppm} /$ 窒素バランス) を用いた。また市販の標 準ガスに含まれない物質は, 今村の方法 ${ }^{16)} に$ 従って標準 物質の混合カクテルを調製し, 真空にしたキャニスター にマイクロシリンジで添加, 気化させ, 加湿純窒素で加 圧希釈することによって標準ガスを調製した。

標準ガスを添加する場合は, 注射筒で一定量採取して真 空にしたキャニスターに添加した。調査対象物質を Table 1 
Table 1 Volatile organic compounds in this study

\begin{tabular}{|c|c|c|c|c|c|c|c|}
\hline No. & Compound name(common name) & Fomula & M.W. & B.P., ${ }^{\circ} \mathrm{C}$ & \multicolumn{3}{|c|}{ Monitor ions $(\mathrm{m} / \mathrm{z})$} \\
\hline 1 & Acetonitrile & $\mathrm{CH} 3 \mathrm{CN}$ & 41.1 & 82 & 40 & 41 & \\
\hline 2 & Acrylonitrile & $\mathrm{CH} 2=\mathrm{CHCN}$ & 53.1 & 77 & 52 & 53 & \\
\hline 3 & Benzene & $\mathrm{C} 6 \mathrm{H} 6$ & 78.1 & 80 & 78 & 77 & \\
\hline 4 & 1-Bromo-3-chloropropane & $\mathrm{CH}_{2} \mathrm{BrCH} 2 \mathrm{CH}_{2} \mathrm{Cl}$ & 157.4 & 142 & 158 & 156 & \\
\hline 5 & 2-Bromopropane & СН3 $\mathrm{CHBrCH} 3$ & 123.0 & 59.0 & 122 & 124 & \\
\hline 6 & 1,3-Butadiene & $\mathrm{CH} 2=\mathrm{CHCH}=\mathrm{CH} 2$ & 54.1 & -5.0 & 54 & 53 & \\
\hline 7 & iso-Butyl acetate & $\mathrm{CH} 3 \mathrm{COOCH} 2 \mathrm{CH}\left(\mathrm{CH}_{3}\right) 2$ & 116.2 & 118 & 73 & 56 & \\
\hline 8 & n-Butyl acetate & $\mathrm{CH}_{3} \mathrm{COOC}_{4} \mathrm{H}_{10}$ & 116.2 & 126.3 & 73 & 56 & \\
\hline 9 & Chlorobenzene & $\mathrm{ClC} 6 \mathrm{H} 5$ & 112.6 & 132.0 & 112 & 77 & \\
\hline 10 & 1-Chlorobutane & $\mathrm{CH}_{2} \mathrm{ClC}_{3} \mathrm{H} 7$ & 92.6 & 78.5 & 56 & 41 & \\
\hline 11 & 1-Chloro-1,1-difluoroethane(HCFC-142b) & $\mathrm{CH} 3 \mathrm{CClF} 2$ & 100.5 & -9.8 & 65 & & \\
\hline 12 & Chlorodifluoromethane(HCFC-22) & $\mathrm{CHClF} 2$ & 86.5 & -40.8 & 51 & 67 & \\
\hline 13 & Chloroethene(Vinylchloride) & $\mathrm{CH} 2=\mathrm{CHCl}$ & 62.5 & -13.9 & 62 & 64 & \\
\hline 14 & Dichloromethane & $\mathrm{CH}_{2} \mathrm{Cl} 2$ & 84.9 & 39.8 & 84 & 86 & \\
\hline 15 & 3-Chloro-1-propene & $\mathrm{CH} 2=\mathrm{CHCH} 2 \mathrm{Cl}$ & 76.5 & 45 & 41 & 76 & \\
\hline 16 & 1,2-Dibromoethane & $\mathrm{CH}_{2} \mathrm{BrCH} 2 \mathrm{Br}$ & 187.9 & 131.3 & 107 & 109 & \\
\hline 17 & 1,2-Dichlorobenzene(o-Dichlorobenzene) & $\mathrm{Cl}_{2} \mathrm{C}_{6} \mathrm{H}_{4}$ & 147.0 & 179.2 & 146 & 148 & \\
\hline 18 & 1,3-Dichlorobenzene(m-Dichlorobenzene) & $\mathrm{Cl} 2 \mathrm{C} 6 \mathrm{H}_{4}$ & 147.0 & 172 & 146 & 148 & \\
\hline 19 & 1,4-Dichlorobenzene(p-Dichlorobenzene) & $\mathrm{Cl}_{2} \mathrm{C} 6 \mathrm{H}_{4}$ & 147.0 & 174 & 146 & 148 & \\
\hline 20 & 3,4-Dichloro-1-butene & $\mathrm{CH} 2=\mathrm{CHCHClCH} 2 \mathrm{Cl}$ & 125.0 & 123 & 75 & 89 & \\
\hline 21 & Dichlorodifluoromethane(CFC12) & $\mathrm{CCl} 2 \mathrm{~F} 2$ & 120.9 & -29.8 & 85 & 87 & \\
\hline 22 & 1,1-Dichloroethane & $\mathrm{CH} 3 \mathrm{CHCl} 2$ & 99.0 & 57.3 & 63 & 65 & \\
\hline 23 & 1,2-Dichloroethane & $\mathrm{CH}_{2} \mathrm{ClCH} 2 \mathrm{Cl}$ & 99.0 & 83 & 62 & 64 & \\
\hline 24 & 1,1-Dichloroethylene & $\mathrm{CH} 2=\mathrm{CCl} 2$ & 96.9 & 32 & 61 & 96 & \\
\hline 25 & 1,2-Dichloroethylene & $\mathrm{CHCl}=\mathrm{CHCl}$ & 96.9 & $47.7,60.6$ & 96 & 98 & \\
\hline 26 & 1,1-Dichloro-1-fluoroethane(HCFC-141b) & $\mathrm{CH}_{3} \mathrm{CCl} 2 \mathrm{~F}$ & 116.9 & 32.0 & 81 & 61 & \\
\hline 27 & 1,1-Dichloro-2,2,3,3,3-pentafluoropropane(HCFC-225ca) & $\mathrm{CF} 3 \mathrm{CF} 2 \mathrm{CHCl} 2$ & 202.9 & 51.1 & 83 & 85 & \\
\hline 28 & 1,3-Dichloro-1,2,2,3,3-pentafluoropropane(HCFC-225cb) & $\mathrm{CClF}_{2} \mathrm{CF}_{2} \mathrm{CHClF}$ & 202.9 & 56.1 & 167 & 100 & \\
\hline 29 & 1,2-Dichloropropane & $\mathrm{CH}_{2} \mathrm{ClCHClCH} 3$ & 113.0 & 97 & 63 & 62 & \\
\hline 30 & cis-1,3-Dichloropropene & $\mathrm{CHCl}=\mathrm{CHCH}=\mathrm{CHCl}$ & 111.0 & 112 & 75 & 77 & \\
\hline 31 & trans-1,3-Dichloropropene & $\mathrm{CHCl}=\mathrm{CHCH}=\mathrm{CHCl}$ & 111.0 & 104 & 75 & 77 & \\
\hline 32 & 1,2-Dichloro-1,1,2,2-tetrafluoroethane(CFC114) & $\mathrm{CClF} 2-\mathrm{CClF} 2$ & 170.9 & 3.6 & 50 & 52 & \\
\hline 33 & 1,1-Dichloro-2,2,2-trifluoroethane(HCFC-123) & $\mathrm{CHCl} 2 \mathrm{CF} 3$ & 152.9 & 27.9 & 85 & 133 & \\
\hline 34 & 1,4-Dioxane & $\mathrm{C} 4 \mathrm{H} 8 \mathrm{O} 2$ & 88.1 & 101 & 88 & 58 & \\
\hline 35 & Ethyl acetate & $\mathrm{CH} 3 \mathrm{COOC} 2 \mathrm{H} 5$ & 88.1 & 76.8 & 70 & 43 & \\
\hline 36 & Ethyl benzene & $\mathrm{C} 2 \mathrm{H} 5 \mathrm{C} 6 \mathrm{H} 5$ & 106.2 & 136.2 & 91 & 106 & \\
\hline 37 & Ethyl bromide(Bromoethane) & $\mathrm{C} 2 \mathrm{H} 5 \mathrm{Br}$ & 109.0 & 38.2 & 108 & 110 & \\
\hline 38 & Ethyl chloride(Chloroethane) & $\mathrm{CH}_{3} \mathrm{CH} 2 \mathrm{Cl}$ & 64.5 & 12 & 64 & 66 & \\
\hline 39 & Ethylene oxide & $\mathrm{C}_{2} \mathrm{H} 4 \mathrm{O}$ & 44.1 & 10.4 & 44 & 29 & \\
\hline 40 & 1,4-Ethyltoluene & $\mathrm{CH} 3 \mathrm{C}_{2} \mathrm{H} 5 \mathrm{C} 6 \mathrm{H} 4$ & 120.2 & 160 & 105 & 120 & \\
\hline 41 & Hexachloro-1,3-butadiene & $\mathrm{CCl} 2=\mathrm{CClCCl}=\mathrm{CCl} 2$ & 260.8 & - & 225 & 227 & \\
\hline 42 & Methyl bromide(Bromomethane) & $\mathrm{CH} 3 \mathrm{Br}$ & 94.9 & 3.6 & 94 & 96 & \\
\hline 43 & Methyl-t-butylether(MTBE) & $(\mathrm{CH} 3) 3 \mathrm{COCH} 3$ & 88.1 & 55.2 & 73 & 57 & \\
\hline 44 & Methyl chloride(Chloromethane) & $\mathrm{CH} 3 \mathrm{Cl}$ & 50.5 & -23.7 & 50 & 52 & \\
\hline 45 & alpha-Methylstyrene & $\mathrm{CH} 3 \mathrm{CCH} 2 \mathrm{C} 6 \mathrm{H} 5$ & 120.1 & 161 & 118 & 117 & \\
\hline 46 & trans-beta-Methylstyrene & $\mathrm{CH} 3 \mathrm{CHCHC} 6 \mathrm{H} 5$ & 120.1 & 174 & 117 & 118 & \\
\hline 47 & Styrene & $\mathrm{CH}=\mathrm{CH} 2 \mathrm{C} 6 \mathrm{H} 5$ & 104.2 & 145.8 & 104 & 103 & \\
\hline 48 & 1,1,2,2-tetrachloroethane & $\mathrm{CHCl} 2 \mathrm{CHCl} 2$ & 167.8 & 146.5 & 83 & 85 & \\
\hline 49 & Tetrachloroethylene & $\mathrm{CCl} 2=\mathrm{CCl} 2$ & 165.8 & 121.2 & 166 & 164 & \\
\hline 50 & 1,2,4-Trichlorobenzene & $\mathrm{Cl}_{3} \mathrm{C} 6 \mathrm{H} 3$ & 181.4 & 213 & 180 & 182 & \\
\hline 51 & 1,1,1,2-tetrafluoroethane(HFC-134a) & $\mathrm{CH} 2 \mathrm{FCF} 3$ & 102.0 & -26.3 & 83 & 69 & \\
\hline 52 & Tetrachloromethane(Carbon tetrachloride) & $\mathrm{CCl} 4$ & 153.8 & 76.5 & 117 & 119 & \\
\hline 53 & 1,1,1-Trichloroethane & $\mathrm{CH} 3 \mathrm{CCl} 3$ & 133.4 & 74.1 & 97 & 99 & \\
\hline 54 & $1,1,2$-Trichloroethane & $\mathrm{CH} 2 \mathrm{ClCHCl} 2$ & 133.4 & 114 & $97 \quad 99$ & 83 & 85 \\
\hline 55 & Trichloroethylene & $\mathrm{CHCl}=\mathrm{CCl} 2$ & 131.4 & 88 & 130 & 132 & \\
\hline 56 & Trichlorofluoromethane(CFC11) & $\mathrm{CCl} 3 \mathrm{~F}$ & 137.4 & 23.7 & 101 & 103 & \\
\hline 57 & Trichloromethane(Chloroform) & $\mathrm{CHCl} 3$ & 119.4 & 61.7 & 83 & 85 & \\
\hline 58 & 1,1,2-Trichloro-1,2,2-trifluoroethane(CFC113) & $\mathrm{CClF} 2-\mathrm{CCl} 2 \mathrm{~F}$ & 187.4 & 47.5 & 151 & 153 & \\
\hline 59 & 1,2,4-Trimethylbenzene & $(\mathrm{CH} 3) 3 \mathrm{C} 6 \mathrm{H} 4$ & 120.2 & 169.3 & 105 & 120 & \\
\hline 60 & 1,3,5-Trimethylbenzene & $(\mathrm{CH} 3)_{3} \mathrm{C}_{6} \mathrm{H}_{4}$ & 120.2 & 164.7 & 105 & 120 & \\
\hline 61 & Toluene & $\mathrm{CH} 3 \mathrm{C} 6 \mathrm{H} 5$ & 92.1 & 110.8 & 91 & 92 & \\
\hline 62 & Vinyl acetate & $\mathrm{CH} 3 \mathrm{COOCH}=\mathrm{CH} 2$ & 86.1 & 73 & 86 & 43 & \\
\hline 63 & 1,2-xylene(o-Xylene) & $(\mathrm{CH} 3)_{2} \mathrm{C} 6 \mathrm{H} 5$ & 106.2 & 142 & 91 & 106 & \\
\hline 64 & 1,3-+1,4-xylene(m-,p-Xylene) & $(\mathrm{CH} 3)_{2} \mathrm{C} 6 \mathrm{H} 5$ & 106.2 & $139,138.4$ & 91 & 106 & \\
\hline inst & Toluene d8 & $\mathrm{CD} 3 \mathrm{C} 6 \mathrm{D} 5$ & 100.2 & - & 98 & 100 & \\
\hline
\end{tabular}


に示す。

\section{4 器具及び装置}

減圧採取用のマスフローコントローラー（MFC）は HEMMI 製 PF5201A3155を使用した。キャニスターの洗 净は Enteck 社製 Model3000洗浄装置を用い, $100^{\circ} \mathrm{C}$ 程度 に加熱しながら減圧及び加湿純窒素による加圧を 8 回繰 り返した。キャニスターに採取した試料は加湿純窒素で 加圧希釈後, 自動大気試料濃縮装置 Enteck 社製 Model7000で濃縮し, Hewlett-Packard 社製 GC/MS HP5973 に導入して定量した。

\section{5 測定条件}

Table 2 に濃縮条件, Table 3 に GC/MS 条件を示す。 SCAN 法またはSIM 法で分析し, トルエン $d 8$ を内部標 準とした相対検量線法で定量した。

\section{6 添加回収実験及び保存安定性試験}

標準ガスを添加したキャニスターと無添加のキャニス ターに MFCを取り付け, $3 \mathrm{~m} \ell / \mathrm{min}$ の流量で 24 時間環境 大気の採取を行った。採取した試料は加湿純窒素で約 10psig まで加圧希釈し，それぞれ分析してその定量值の 差から添加回収率を求めた。分析した試料はそのまま実 験室内で保存し，4 日後から88日後に再度分析した。再 分析時には, 標準ガスを分析して検量線を引き直し, 定 量した值を保存前の定量値と比較した。

\section{7 環境試料の保存安定性試釦}

試料採取用に調製したキャニスターにMFCを取り付 け, $3 \mathrm{~m} \ell / \mathrm{min}$ の流量で 24 時間環境大気の採取を行っ た。採取した試料は加湿純窒素で約10psig まで加圧希釈 し，それぞれ分析した。分析した試料はそのまま実験室 内で保存し，最長30日後に再度分析した。

\section{3. 結果及び考察}

\section{1 添加回収実跧結果}

64物質の添加回収実験の結果と検出限界值 (LOD) を Table 4に示す。0.01ppbv または0.05ppbvの標準試料 を 5 回繰り返して測定し, 得られた定量值の相対標準偏 差の 3 倍值をLOD とした。Table 4 中に示した 4 回の実 験結果では, 試料採取後 5 日以内に分析した場合の回収 率は，64物質中59物質が 4 回とも80〜120\%の範囲内に はいり，概ね良好な結果が得られた。SIS-SUMMA 缶か らは最大で $2 \mathrm{ppbv}$ の1,4-ジオキサンのブランクが検出 された。洗浄を繰り返すと徐々に低下した。製造工程で 1,4-ジオキサンと何らかの接触があり, 容器内に吸着 して残留していたものと思われる。Table 4中の1,4-ジ オキサン回収率が $300 \%$ を超えているのはこのためであ る。

\section{2 試料の保存安定性}

添加回収実験に用いた試料の保存安定性を検討した結 果をTable 4に示す。1997年12月に採取した試料では， トリクロロベンゼン，スチレン，1,3-ブタジエンなど 二重結合を持つ物質, 置換基を持つ芳香族炭化水素を中

Table 2 Conditions of Entech 7000 Air Preconcentrator

\begin{tabular}{lccc}
\hline Module 1 (glass beads) & Module 2 (Tenax TA) \\
Trap temp. & $-155^{\circ} \mathrm{C}$ & Trap temp. & $-15^{\circ} \mathrm{C}$ \\
IS volume & $100 \mathrm{m \ell}$ & Desorb temp. $180^{\circ} \mathrm{C}$ \\
Sample volume & $400 \mathrm{~m} \ell$ & Module 3 (Sil ico steel) \\
Desorb temp. & $20^{\circ} \mathrm{C}$ & Trap temp. & $-160^{\circ} \mathrm{C}$ \\
Desorb flow & $10 \mathrm{~m} \ell / \mathrm{min}$ & Desorb temp. & $70 \sim 80^{\circ} \mathrm{C}$ \\
\hline
\end{tabular}

Table 3 Operating conditions for $\mathrm{GC} / \mathrm{MS}$

\begin{tabular}{|c|c|}
\hline \multicolumn{2}{|l|}{ GC (HP6890) } \\
\hline Column 1 & $\mathrm{HP}-160 \mathrm{~m} \times 0.25 \mathrm{~mm}$ i. d. $\times 0.25 \mu \mathrm{m}$ film thickness \\
\hline Column temp. & $40(4 \mathrm{~min}) \rightarrow 10^{\circ} \mathrm{C} / \mathrm{min} \rightarrow 250^{\circ} \mathrm{C}(5 \mathrm{~min})$ \\
\hline Column 2 & DB- $62460 \mathrm{~m} \times 0.25 \mathrm{~mm}$ i. d. $\times 1.8 \mu \mathrm{m}$ film thickness \\
\hline Column temp. & $40(4 \mathrm{~min}) \rightarrow 10^{\circ} \mathrm{C} / \mathrm{min} \rightarrow 250^{\circ} \mathrm{C}(5 \mathrm{~min})$ \\
\hline Column 3 & HP-VOC $60 \mathrm{~m} \times 0.32 \mathrm{~mm}$ i. d. $\times 1.8 \mu \mathrm{m}$ film thickness \\
\hline Column temp. & $40(4 \mathrm{~min}) \rightarrow 10^{\circ} \mathrm{C} / \mathrm{min} \rightarrow 250^{\circ} \mathrm{C}(5 \mathrm{~min})$ \\
\hline Carrier gas & He ( $1 \mathrm{ml} / \mathrm{min}$, constant flow mode) \\
\hline Interface temp. & $250^{\circ} \mathrm{C}$ \\
\hline MS (HP5973) & \\
\hline Ion source temp. & $230^{\circ} \mathrm{C}$ \\
\hline Mode & SIM, SCAN \\
\hline
\end{tabular}


心に，保存期間が長くなるに従って回収率は減少する傾 向を示したが，2000年 2 月に採取した試料では，それら の物質の保存安定性は良好だった。2つの実験は，標準 物質の添加濃度が違う他はすべて同じ条件で実施され た。それぞれの試料採取日について，採取地点近傍の大 気污染常時監視測定局の観測デー夕を検討した結果，窒 素酸化物, 光化学オキシダント, SPM な゙の污染物質 濃度も, 気温, 湿度などの気象条件も，特徵が見られる ものは見つからなかった。回収率が低下した物質では, 個々のキャニスターの回収率は，保存期間が長くなるに 従って差が広がる傾向が見られ，キャニスターの個体差 が保存安定性に影響を与えていると思われた。一方，2 つの実験には同一のキャニスターが 2 個使用されてお り，いずれも1997年の実験では回収率低下が見られた が，2000年の実験では 2 個ともに保存安定性良好であっ た。このため, 濃度低下が起こる場合と起きない場合が あった原因は，キャニスターの個体差とともに，常時監 視測定局では測定されていない環境大気中の共存物質の 影響である可能性が高いと思われる。キャニスター内の 物質の安定性は環境大気中の共存物質によって影響を受 け，その程度は試料の組成によって変動するため, 試料 採取日によって保存安定性に差が現れたと考えられる。

環境大気試料の保存安定性を検討した結果を Table 5 に示す。43物質が検出された。アクリロニトリルは, 標 準物質を添加したキャニスターではほほ安定であった が，濃度の低い環境試料では保存期間が長くなるに従っ て増加する傾向があった。酸化エチレンは保存期間が長 くなると濃度が上昇する傾向があり, その上昇割合は環 境試料の方が高かった。この傾向は Silico 缶, 2 社の SUMMA 缶に共通して見られた。Table 5のアンダーラ インを付した数值は，保存後の数值の変動が $20 \%$ 超え たものである。1,3-ブタジエンは Silico 缶で減少傾向を 示し，アクリロニトリルと酸化エチレンはSilico 缶, SUMMA 缶ともに増加傾向を示した。このようにキャニ スターに採取した試料中の化学物質濃度は，保存期間が 長くなると変化する可能性があることがわかったので, 定量分析はできるだけ速やかに行う必要がある。

Table 5中に太字で表示した28物質はすべての実験で 良好な保存安定性を示した物質で, これらは 1 ヶ月程度 保存しても定量分析が可能であることがわかった。

\section{3 ブランク值の変動}

Daughtrey らは $n$-オクタナールの測定結果をもとに, キャニスター内に洗浄しても除去しきれないアルデヒド が残留するため，上り優れた洗浄方法が開発されるまで はキャニスターによるアルデヒド測定は困難であると報 告している3”。著者の実験では残留するだけでなく，保 存安定性の検討中にアセトアルデヒド，プロピオンアル
デヒドなど，キャニスター内のアルデヒド類濃度が上昇 する現象が観察された。最大アセトアルデヒドが約 7 ppbv 上昇した。超純水 $100 \mu \ell$ を添加し，加湿純窒素で 加圧した操作ブランク測定用のキャニスターや新品の キャニスターでも同様の現象が観察された。一方で全く アルデヒド類の濃度上昇が観察されないキャニスターも あった。アルデヒド類の標準ガスを調製したキャニス ターは，洗浄後濃度上昇を起こさなかった。これはキャ ニスター内の気相に存在したアルデヒド類は通常の洗浄 で除去可能であることを示している。このため, 濃度上 昇の原因は採取した試料の影響や実験室からの污染では なく，個々のキャニスタ一自体にあると考えた ${ }^{14}$ 。濃度 上昇の程度が大きかったキャニスターを通常の手順で洗 浄し, 純水添加は行わず加湿純窒素を約10psig まで充填 して分析した。分析後キャニスターのバルブを閉め, 濃 縮装置に接続したまま実験室内で保存し，42日後に再度 分析した GC/MS のクロマトグラムを Fig. 1に示す。上 が洗浄直後，下が42日後である。トータルイオンクロマ トグラム（TIC）で見ると，アセトアルデヒド，プロピ オンアルデヒドなどのアルデヒド類や内壁の溶融シリカ 処理由来と考えられるシリコン化合物のピークが増大し ているのがわかった。またTICでは判別できないが， 個々のイオンクロマトグラムを見ると，アクリロニトリ ルのピークが増大しているのがわかった。このピークの 増大分は約 $0.01 \mathrm{ppbv} に$ に相当する。再度洗浄するとピー クは小さくなった。アセトアルデヒドなどのピークが増 大寸る現象は純水添加した Silico 缶20個中 9 個, SISSUMMA 缶 9 個中 3 個, SIBATA-SUMMA 缶 7 個中 2 個, 純水添加しないSilico 缶18個中 2 個で観察された。 いずれも再度洗浄すると増大したピークは元に戻った。 内面处理法の違うキャニスターで同様の現象が見られる ことから，キャニスター本体のステンレスや構成部品に 吸着して残留していた極性物質もしくはその分解生成物 が，徐々に気相に移行している可能性が高いと考えられ る。Silico 缶の場合, 純水添加したキャニスターの方が アルデヒド類の濃度上昇が大きい傾向があったが，吸着 物質が水分子と置換されて気相に移行しやすくなるので はないかと思われる。環境試料の保存性試験で，アクリ ロニトリル，酸化エチレンの濃度が増大したのはこのた めと考えられる。

\section{4 環境モニタリング調查の精度管理}

Table 5の中から，キャニスターを用いて環境モニタ リング調査が実施されている塩化ビニル，1,3-ブタジ エン，アクリロニトリル，ジクロロメタン，クロロホル ム，1,2-ジクロロエタン, ベンゼン，トリクロロエチ レン及びテトラクロロエチレンの結果を見ると, 環境試 料の保存後の分析值はアクリロニトリルが最大 $0.04 \mathrm{ppbv}$ 
Table 4-1 Method detection of limits (LOD), 1 88-day stability recoveries of standard spiked in urban air sample

\begin{tabular}{|c|c|c|c|c|c|c|c|c|c|}
\hline & pure w & $\begin{array}{r}\text { ling date } \\
\text { ard spike } \\
\text { ike }(\mu \mathrm{L}) \\
\text { ter type } \\
\mathrm{n}\end{array}$ & & & $\begin{array}{l}997 \\
\text { bv } \\
0 \\
\text { co }\end{array}$ & & & $\begin{array}{c}\text { Feb.2000 } \\
0.4 p p b v \\
100 \\
\text { Silico } \\
5 \\
\end{array}$ & \\
\hline No. & compound & LOD & & stability & recovery) & & stak & ity $(\%$ recc & very) \\
\hline & & ppbv & 1day & 5days & 27days & 88days & 1day & 12days & 46days \\
\hline 1 & Acetonitrile & 0.013 & & & & & 98 & 116 & 81 \\
\hline 2 & Acrylonitrile & 0.005 & 98 & 99 & 92 & 77 & 100 & 103 & 104 \\
\hline 3 & Benzene & 0.005 & 102 & 99 & 101 & 99 & 99 & 100 & 105 \\
\hline 4 & 1-Bromo-3-chloropropane & 0.002 & & & & & & & \\
\hline 5 & 2-Bromopropane & 0.005 & 91 & 100 & 101 & & & & \\
\hline 6 & 1,3-Butadiene & 0.004 & 82 & 84 & 60 & 40 & 102 & 102 & 111 \\
\hline 7 & iso-Butyl acetate & 0.011 & & & & & 95 & 87 & 100 \\
\hline 8 & n-Butyl acetate & 0.002 & & & & & 75 & 63 & 47 \\
\hline 9 & Chlorobenzene & 0.002 & 97 & 99 & 100 & 94 & & & \\
\hline 10 & 1-Chlorobutane & 0.009 & 96 & 99 & 90 & & & & \\
\hline 11 & HCFC-142b & 0.002 & & & & & 106 & 98 & 107 \\
\hline 12 & HCFC-22 & 0.006 & & & & & 104 & 98 & 108 \\
\hline 13 & Vinylchloride & 0.002 & 100 & 96 & 94 & 91 & 108 & 98 & 116 \\
\hline 14 & Dichloromethane & 0.015 & 114 & 98 & 95 & 97 & 91 & 92 & 99 \\
\hline 15 & 3-Chloro-1-propene & 0.013 & 106 & 109 & 56 & 52 & & & \\
\hline 16 & 1,2-Dibromoethane & 0.001 & 99 & 101 & 103 & 101 & & & \\
\hline 17 & o-Dichlorobenzene & 0.004 & 109 & 101 & 99 & 90 & 102 & 100 & 103 \\
\hline 18 & m-Dichlorobenzene & 0.004 & 97 & 102 & 100 & 91 & 102 & 101 & 104 \\
\hline 19 & p-Dichlorobenzene & 0.008 & 100 & 101 & 98 & 95 & 100 & 96 & 101 \\
\hline 20 & 3,4-Dichloro-1-butene & 0.006 & 84 & 95 & 90 & & & & \\
\hline 21 & $\mathrm{CFC} 12$ & 0.005 & 106 & 101 & 105 & 104 & 102 & 99 & 113 \\
\hline 22 & 1,1-Dichloroethane & 0.002 & 103 & 100 & 99 & 102 & & & \\
\hline 23 & 1,2-Dichloroethane & 0.004 & 104 & 104 & 107 & 106 & 106 & 98 & 107 \\
\hline 24 & 1,1-Dichloroethylene & 0.004 & 94 & 97 & 93 & 87 & & & \\
\hline 25 & 1,2-Dichloroethylene & 0.002 & 98 & 99 & 101 & 99 & & & \\
\hline 26 & HCFC-141b & 0.001 & & & & & 105 & 98 & 108 \\
\hline 27 & HCFC-225ca & 0.001 & & & & & 105 & 98 & 109 \\
\hline 28 & HCFC-225cb & 0.002 & & & & & 106 & 99 & 115 \\
\hline 29 & 1,2-Dichloropropane & 0.001 & 108 & 100 & 102 & 103 & 107 & 98 & 106 \\
\hline 30 & cis-1,3-Dichloropropene & 0.004 & 84 & 94 & 88 & 76 & & & \\
\hline 31 & trans-1,3-Dichloropropene & 0.003 & 93 & 98 & 94 & 88 & & & \\
\hline 32 & CFC114 & 0.004 & 106 & 99 & 101 & 101 & & & \\
\hline 33 & HCFC-123 & 0.001 & & & & & 106 & 98 & 110 \\
\hline 34 & 1,4-Dioxane & 0.008 & & & & & 87 & 72 & 42 \\
\hline 35 & Ethyl acetate & 0.010 & & & & & 96 & 88 & 100 \\
\hline 36 & Ethylbenzene & 0.017 & 100 & 98 & 95 & 77 & 101 & 99 & 102 \\
\hline 37 & Bromoethane & 0.005 & 91 & 101 & 100 & & & & \\
\hline 38 & Chloroethane & 0.006 & 109 & 96 & 98 & 98 & & & \\
\hline 39 & Ethylene oxide & 0.007 & & & & & 104 & 116 & 165 \\
\hline 40 & p-Ethyltoluene & 0.004 & 88 & 97 & 86 & 42 & 94 & 101 & 85 \\
\hline 41 & Hexachloro-1,3-butadiene & 0.010 & 112 & 103 & 108 & 106 & & & \\
\hline 42 & Bromomethane & 0.004 & 104 & 99 & 98 & 100 & & & \\
\hline 43 & MTBE & 0.005 & & & & & & & \\
\hline 44 & Chloromethane & 0.005 & 107 & 98 & 100 & 103 & 102 & 95 & 101 \\
\hline 45 & alpha-Methylstyrene & 0.001 & & & & & & & \\
\hline 46 & trans-beta-Methylstyrene & 0.001 & & & & & & & \\
\hline 47 & Styrene & 0.007 & 80 & 86 & 63 & 18 & 101 & 97 & 100 \\
\hline 48 & 1,1,2,2-tetrachloroethane & 0.002 & 86 & 101 & 100 & 97 & & & \\
\hline 49 & Tetrachloroethylene & 0.014 & 93 & 101 & 103 & 102 & 103 & 96 & 108 \\
\hline 50 & 1,2,4-Trichlorobenzene & 0.002 & 109 & 96 & 100 & 88 & & & \\
\hline 51 & $\mathrm{HFC}-134 \mathrm{a}$ & 0.005 & & & & & 100 & 101 & 101 \\
\hline 52 & Carbon tetrachloride & 0.002 & 89 & 96 & 100 & 100 & 105 & 97 & 108 \\
\hline 53 & 1,1,1-Trichloroethane & 0.002 & 106 & 100 & 103 & 103 & 107 & 92 & 104 \\
\hline 54 & 1,1,2-Trichloroethane & 0.004 & 107 & 102 & 103 & 103 & & & \\
\hline 55 & Trichloroethylene & 0.008 & 113 & 100 & 101 & 100 & 103 & 97 & 104 \\
\hline 56 & CFC11 & 0.002 & 103 & 102 & 104 & 102 & 104 & 97 & 106 \\
\hline 57 & Chloroform & 0.003 & 101 & 100 & 102 & 103 & 106 & 97 & 111 \\
\hline 58 & $\mathrm{CFC} 113$ & 0.003 & 100 & 101 & 103 & 104 & 102 & 97 & 104 \\
\hline 59 & 1,2,4-Trimethylbenzene & 0.003 & 81 & 92 & 72 & 25 & 102 & 97 & 99 \\
\hline 60 & 1,3,5-Trimethylbenzene & 0.006 & 81 & 85 & 59 & 17 & 94 & 102 & 92 \\
\hline 61 & Toluene & 0.011 & 112 & 96 & 93 & 88 & 101 & 99 & 104 \\
\hline 62 & Vinyl acetate & 0.003 & & & & & 72 & 66 & 59 \\
\hline 63 & o-X̌ylene & 0.002 & 95 & 98 & 91 & 61 & 102 & 98 & 102 \\
\hline 64 & m-,p-Xylene & 0.003 & 101 & 96 & 87 & 58 & 102 & 99 & 102 \\
\hline
\end{tabular}

LOD were 3 times standard deviation $(n=5)$ calculated from quantitative amount of $0.01 \mathrm{ppbv}$ standard gas. LOD(italic) were calculated from $0.05 \mathrm{ppbv}$ standard gas.

All samples were obtained in Kanagawa ,Hiratsuka-city(industrial area) for $24 \mathrm{~h}$. 
Table 4-2 Method detection of limits (LOD), 1 88-day stability recoveries of standard spiked in urban air sample (continued)

\begin{tabular}{|c|c|c|c|c|c|c|c|}
\hline \multirow{3}{*}{ No. } & \multirow[t]{3}{*}{$\begin{array}{r}\text { sampling date } \\
\text { standard spike } \\
\text { pure water spike }(\mu \mathrm{L}) \\
\text { canister type } \\
\mathrm{n}\end{array}$} & \multicolumn{3}{|c|}{$\begin{array}{c}\text { Mar.1998 } \\
\text { 2ppbv } \\
100 \\
\text { SUMMA } \\
2 \\
\end{array}$} & & \multicolumn{2}{|c|}{$\begin{array}{c}\text { Oct.2000 } \\
1 \mathrm{ppbv} \\
0 \\
\text { Silico } \\
3 \\
\end{array}$} \\
\hline & & \multirow[b]{2}{*}{ Odays } & \multicolumn{2}{|c|}{ stability(\% recovery) } & \multirow[b]{2}{*}{ 42days } & \multicolumn{2}{|c|}{ stability(\% recovery) } \\
\hline & & & 4days & 26days & & Odays & 13days \\
\hline 1 & Acetonitrile & & & & & & \\
\hline 2 & Acrylonitrile & 107 & 103 & 102 & 99 & 98 & 93 \\
\hline 3 & Benzene & 103 & 115 & 115 & 119 & 81 & 110 \\
\hline 4 & 1-Bromo-3-chloropropane & 89 & 86 & $*$ & & & \\
\hline 5 & 2-Bromopropane & 92 & 109 & & & & \\
\hline 6 & 1,3-Butadiene & 94 & 108 & 104 & 105 & 113 & 92 \\
\hline 7 & iso-Butyl acetate & & & & & 111 & 112 \\
\hline 8 & n-Butyl acetate & & & & & 113 & 87 \\
\hline 9 & Chlorobenzene & 95 & 106 & 98 & 117 & & \\
\hline 10 & 1-Chlorobutane & 84 & 109 & & & & \\
\hline 11 & HCFC-142b & 101 & 92 & $*$ & & 119 & 95 \\
\hline 12 & HCFC-22 & 89 & 95 & $*$ & & 100 & 95 \\
\hline 13 & Vinylchloride & 94 & 106 & 109 & 105 & 113 & 96 \\
\hline 14 & Dichloromethane & 101 & 118 & 108 & 114 & 111 & 105 \\
\hline 15 & 3-Chloro-1-propene & 98 & 110 & 110 & 97 & & \\
\hline 16 & 1,2-Dibromoethane & 98 & 113 & 111 & 113 & & \\
\hline 17 & o-Dichlorobenzene & 88 & 107 & 98 & 98 & 101 & 102 \\
\hline 18 & m-Dichlorobenzene & 95 & 106 & 106 & 96 & 101 & 103 \\
\hline 19 & p-Dichlorobenzene & 94 & 107 & 105 & 96 & 103 & 105 \\
\hline 20 & 3,4-Dichloro-1-butene & 92 & 107 & & & & \\
\hline 21 & $\mathrm{CFC} 12$ & 87 & 104 & 88 & 99 & 112 & 95 \\
\hline 22 & 1,1-Dichloroethane & 90 & 103 & 101 & 104 & & \\
\hline 23 & 1,2-Dichloroethane & 90 & 105 & 101 & 108 & 115 & 99 \\
\hline 24 & 1,1-Dichloroethylene & 105 & 111 & 113 & 116 & & \\
\hline 25 & 1,2-Dichloroethylene & 102 & 116 & 113 & 118 & & \\
\hline 26 & HCFC-141b & 100 & 93 & $*$ & & 116 & 94 \\
\hline 27 & HCFC-225ca & 94 & * 100 & $*$ & & 106 & 96 \\
\hline 28 & HCFC-225cb & 98 & * 101 & $*$ & & 111 & 97 \\
\hline 29 & 1,2-Dichloropropane & 100 & 113 & 109 & 117 & 105 & 100 \\
\hline 30 & cis-1,3-Dichloropropene & 100 & 103 & 108 & 107 & & \\
\hline 31 & trans-1,3-Dichloropropene & 101 & 105 & 105 & 111 & & \\
\hline 32 & CFC114 & 90 & 105 & 105 & 118 & & \\
\hline 33 & HCFC-123 & 97 & 100 & $*$ & & 110 & 91 \\
\hline 34 & 1,4-Dioxane & 307 & 369 & $*$ & & 89 & 104 \\
\hline 35 & Ethyl acetate & & & & & 109 & 97 \\
\hline 36 & Ethylbenzene & 114 & 108 & 114 & 98 & 104 & 95 \\
\hline 37 & Bromoethane & 92 & 106 & & & & \\
\hline 38 & Chloroethane & 93 & 104 & 107 & 106 & 113 & 92 \\
\hline 39 & Ethylene oxide & 100 & * 127 & $*$ & & 113 & 103 \\
\hline 40 & p-Ethyltoluene & 98 & 108 & 103 & 92 & 118 & 108 \\
\hline 41 & Hexachloro-1,3-butadiene & 75 & 107 & 69 & 88 & & \\
\hline 42 & Bromomethane & 90 & 106 & 99 & 107 & & \\
\hline 43 & MTBE & 90 & 85 & $*$ & & & \\
\hline 44 & Chloromethane & 104 & 106 & 108 & 115 & 108 & 96 \\
\hline 45 & alpha-Methylstyrene & & & & & 96 & 89 \\
\hline 46 & trans-beta-Methylstyrene & & & & & 96 & 91 \\
\hline 47 & Styrene & 97 & 109 & 110 & 95 & 107 & 101 \\
\hline 48 & 1,1,2,2-tetrachloroethane & 88 & 114 & 112 & 116 & & \\
\hline 49 & Tetrachloroethylene & 95 & 109 & 102 & 115 & 102 & 102 \\
\hline 50 & 1,2,4-Trichlorobenzene & 85 & 113 & 79 & 90 & & \\
\hline 51 & HFC-134a & 95 & 92 & $*$ & & 110 & 96 \\
\hline 52 & Carbon tetrachloride & 86 & 105 & 96 & 101 & 113 & 101 \\
\hline 53 & 1,1,1-Trichloroethane & 87 & 106 & 91 & 101 & 109 & 100 \\
\hline 54 & 1,1,2-Trichloroethane & 98 & 114 & 106 & 115 & 106 & 103 \\
\hline 55 & Trichloroethylene & 103 & 116 & 90 & 93 & 101 & 101 \\
\hline 56 & CFC11 & 87 & 103 & 90 & 99 & 114 & 93 \\
\hline 57 & Chloroform & 89 & 105 & 95 & 101 & 108 & 95 \\
\hline 58 & $\mathrm{CFC} 113$ & 86 & 103 & 90 & 99 & 104 & 97 \\
\hline 59 & 1,2,4-Trimethylbenzene & 102 & 111 & 111 & 89 & 116 & 100 \\
\hline 60 & $1,3,5$-Trimethylbenzene & 92 & 108 & 99 & 89 & 104 & 97 \\
\hline 61 & Toluene & 97 & 108 & 100 & 107 & 98 & 102 \\
\hline 62 & Vinyl acetate & & & & & 110 & 99 \\
\hline 63 & o-Xylene & 100 & 108 & 107 & 95 & 108 & 99 \\
\hline 64 & $\mathrm{~m}-\mathrm{p}$-Xylene & 105 & 109 & 110 & 100 & 108 & 99 \\
\hline
\end{tabular}


Table 5 Detected air concentrations and stability of analytes in urban air sample

\begin{tabular}{|c|c|c|c|c|c|c|c|c|c|}
\hline \multirow[t]{3}{*}{$\begin{array}{r}\text { sampling date } \\
\text { pure water spike }(\boldsymbol{\mu} \mathrm{L}) \\
\text { canister type } \\
\mathrm{n}\end{array}$} & \multicolumn{2}{|c|}{$\begin{array}{l}\text { May.1999 } \\
100 \\
\text { Silico } \\
7 \\
\end{array}$} & \multicolumn{3}{|c|}{$\begin{array}{l}\text { Oct.1999 } \\
100 \\
\text { SUMMA } \\
8 \\
\end{array}$} & \multicolumn{2}{|c|}{$\begin{array}{c}\text { Aug.2000 } \\
0 \\
\text { Silico }\end{array}$} & & Silico \\
\hline & \multicolumn{2}{|c|}{$\begin{array}{c}\text { stability } \\
\text { (ppbv:detected value) }\end{array}$} & \multicolumn{3}{|c|}{$\begin{array}{c}\text { stability } \\
\text { (ppbv:detected value) }\end{array}$} & \multicolumn{2}{|c|}{$\begin{array}{c}\text { stability } \\
\text { (ppbv:detected value) }\end{array}$} & \multicolumn{2}{|c|}{$\begin{array}{c}\text { stability } \\
\text { (ppbv:detected value) }\end{array}$} \\
\hline & 7days & 30days & Odays & 7days & 28days & 2days & 14days & Odays & 30days \\
\hline 1 Acetonitrile & n.a. & n.a. & n.a. & n.a. & n.a. & 0.27 & 0.23 & n.a. & n.a. \\
\hline 2 Acrylonitrile & 0.051 & 0.080 & 0.051 & 0.076 & 0.094 & 0.091 & $\mathbf{0 . 1 3}$ & 0.061 & 0.081 \\
\hline 3 Benzene & 0.73 & 0.87 & 1.6 & 1.6 & 1.6 & 0.77 & 0.77 & 0.99 & 1.1 \\
\hline 4 1-Bromo-3-chloropropane & n.a. & n.a. & n.a. & n.a. & n.a. & n.a. & n.a. & n.a. & n.a. \\
\hline 5 2-Bromopropane & n.a. & n.a. & n.a. & n.a. & n.a. & n.a. & n.a. & n.a. & n.a. \\
\hline 6 1,3-Butadiene & 0.10 & 0.08 & 0.14 & 0.14 & 0.14 & 0.14 & 0.11 & 0.25 & 0.23 \\
\hline 7 iso-Butyl acetate & n.a. & n.a. & n.a. & n.a. & n.a. & n.d. & n.d. & 0.064 & 0.071 \\
\hline 8 n-Butyl acetate & n.a. & n.a. & n.a. & n.a. & n.a. & 0.057 & 0.051 & 0.44 & 0.52 \\
\hline 9 Chlorobenzene & n.a. & n.a. & n.a. & n.a. & n.a. & n.a. & n.a. & n.a. & n.a. \\
\hline 10 1-Chlorobutane & n.a. & n.a. & n.a. & n.a. & n.a. & n.a. & n.a. & n.a. & n.a. \\
\hline 11 HCFC-142b & 0.086 & 0.097 & 0.19 & 0.21 & 0.21 & 0.057 & 0.063 & 0.045 & 0.048 \\
\hline 12 HCFC-22 & 0.37 & 0.41 & 0.73 & 0.74 & 0.80 & 0.44 & 0.47 & 0.48 & 0.50 \\
\hline 13 Vinylchloride & 0.048 & 0.052 & 0.26 & 0.26 & 0.28 & 0.028 & 0.031 & 0.038 & 0.038 \\
\hline 14 Dichloromethane & 1.8 & 2.2 & 5.4 & 5.4 & 5.6 & 1.0 & 1.0 & 2.7 & 2.7 \\
\hline 15 3-Chloro-1-propene & n.a. & n.a. & n.a. & n.a. & n.a. & n.a. & n.a. & n.a. & n.a. \\
\hline 16 1,2-Dibromoethane & n.a. & n.a. & n.a. & n.a. & n.a. & n.a. & n.a. & n.a. & n.a. \\
\hline 17 o-Dichlorobenzene & n.d. & n.d. & n.d. & n.d. & n.d. & 0.008 & 0.009 & 0.008 & 0.008 \\
\hline $18 \mathrm{~m}$-Dichlorobenzene & n.d. & n.d. & n.d. & n.d. & n.d. & n.d. & n.d. & n.d. & n.d. \\
\hline 19 p-Dichlorobenzene & 0.44 & 0.52 & 0.57 & 0.55 & 0.58 & 1.5 & 1.5 & 0.47 & 0.48 \\
\hline 20 3,4-Dichloro-1-butene & n.a. & n.a. & n.a. & n.a. & n.a. & n.a. & n.a. & n.a. & n.a. \\
\hline 21 CFC12 & 0.65 & 0.73 & 0.99 & 0.91 & 0.96 & 0.64 & 0.69 & 0.65 & 0.68 \\
\hline 22 1,1-Dichloroethane & n.a. & n.a. & n.a. & n.a. & n.a. & n.a. & n.a. & n.a. & n.a. \\
\hline 23 1,2-Dichloroethane & 0.14 & 0.15 & 0.21 & 0.23 & 0.23 & 0.049 & 0.052 & 0.028 & 0.030 \\
\hline 24 1,1-Dichloroethylene & n.a. & n.a. & n.a. & n.a. & n.a. & n.a. & n.a. & n.a. & n.a. \\
\hline 25 1,2-Dichloroethylene & n.a. & n.a. & n.a. & n.a. & n.a. & n.a. & n.a. & n.a. & n.a. \\
\hline 26 HCFC-141b & 0.24 & 0.26 & 0.25 & 0.26 & 0.27 & 0.11 & 0.12 & 0.15 & 0.16 \\
\hline 27 HCFC-225ca & 0.009 & 0.009 & 0.020 & 0.021 & 0.020 & 0.009 & 0.009 & 0.019 & 0.022 \\
\hline 28 HCFC-225cb & 0.009 & 0.010 & 0.019 & 0.020 & 0.018 & 0.009 & 0.009 & 0.018 & 0.020 \\
\hline 29 1,2-Dichloropropane & 0.017 & 0.018 & 0.027 & 0.029 & 0.032 & 0.006 & 0.007 & 0.025 & 0.026 \\
\hline 30 cis-1,3-Dichloropropene & n.a. & n.a. & n.a. & n.a. & n.a. & n.a. & n.a. & n.a. & n.a. \\
\hline 31 trans-1,3-Dichloropropene & n.a. & n.a. & n.a. & n.a. & n.a. & n.a. & n.a. & n.a. & n.a. \\
\hline 32 CFC114 & n.a. & n.a. & n.a. & n.a. & n.a. & n.a. & n.a. & n.a. & n.a. \\
\hline 33 HCFC-123 & 0.002 & 0.003 & 0.002 & 0.002 & 0.002 & 0.010 & 0.011 & 0.045 & 0.048 \\
\hline 34 1,4-Dioxane & n.a. & n.a. & 0.26 & 0.21 & 0.14 & n.d. & n.d. & 0.02 & 0.01 \\
\hline 35 Ethyl acetate & n.a. & n.a. & n.a. & n.a. & n.a. & 1.3 & 1.1 & 2.7 & 3.0 \\
\hline 36 Ethylbenzene & 1.3 & 1.3 & 1.7 & 1.7 & 1.8 & 0.69 & 0.74 & 1.6 & 1.7 \\
\hline 37 Bromoethane & n.a. & n.a. & n.a. & n.a. & n.a. & n.a. & n.a. & n.a. & n.a. \\
\hline 38 Chloroethane & n.a. & n.a. & n.a. & n.a. & n.a. & n.a. & n.a. & 0.030 & 0.032 \\
\hline 39 Ethylene oxide & 0.08 & 0.17 & 0.18 & 0.24 & 0.41 & 0.04 & 0.06 & 0.06 & 0.07 \\
\hline 40 p-Ethyltoluene & $\overline{0.03}$ & $\overline{0.04}$ & $\overline{0.031}$ & 0.033 & 0.033 & 0.038 & 0.044 & 0.097 & 0.073 \\
\hline 41 Hexachloro-1,3-butadiene & n.a. & n.a. & n.a. & n.a. & n.a. & n.a. & n.a. & n.a. & n.a. \\
\hline 42 Bromomethane & n.a. & n.a. & n.a. & n.a. & n.a. & n.a. & n.a. & n.a. & n.a. \\
\hline $43 \mathrm{MTBE}$ & n.a. & n.a. & n.a. & n.a. & n.a. & n.a. & n.a. & n.a. & n.a. \\
\hline 44 Chloromethane & n.a. & n.a. & n.a. & n.a. & n.a. & n.a. & n.a. & 0.82 & 0.83 \\
\hline 45 alpha-methyistyrene & n.a. & n.a. & n.a. & n.a. & n.a. & n.a. & n.a. & 0.012 & 0.012 \\
\hline 46 tras-beta-methylstyrene & n.a. & n.a. & n.a. & n.a. & n.a. & n.a. & n.a. & 0.012 & 0.011 \\
\hline 47 Styrene & 1.0 & 1.0 & 1.5 & 1.5 & 1.5 & 0.27 & 0.30 & 0.28 & 0.25 \\
\hline $\begin{array}{l}48 \text { 1,1,2,2-tetrachloroethane } \\
49 \text { Tetrachloroethylene }\end{array}$ & $\begin{array}{l}\text { n.a. } \\
0.16\end{array}$ & $\begin{array}{l}\text { n.a. } \\
0.16\end{array}$ & $\begin{array}{l}\text { n.a. } \\
0.35\end{array}$ & $\begin{array}{l}\text { n.a. } \\
0.33\end{array}$ & $\begin{array}{l}\text { n.a. } \\
0.36\end{array}$ & $\begin{array}{l}\text { n.a. } \\
0.060\end{array}$ & $\begin{array}{l}\text { n.a. } \\
0.065\end{array}$ & $\begin{array}{l}\text { n.a. } \\
0.19\end{array}$ & n.a. \\
\hline 50 1,2,4-Trichlorobenzene & n.a. & n.a. & n.a. & n.a. & n.a. & n.a. & n.a. & $\begin{array}{l}0.15 \\
\text { n.a. }\end{array}$ & $\begin{array}{l}0 . c 0 \\
\text { n.a. }\end{array}$ \\
\hline 51 HFC-134a & 0.073 & 0.086 & 4.3 & 4.1 & 4.1 & 0.19 & 0.21 & 0.23 & 0.24 \\
\hline 52 Carbon tetrachloride & 0.11 & 0.12 & 0.14 & 0.15 & 0.14 & 0.12 & 0.13 & 0.12 & 0.13 \\
\hline 53 1,1,1-Trichloroethane & 0.21 & 0.22 & 0.28 & 0.28 & 0.27 & 0.087 & 0.092 & 0.16 & 0.17 \\
\hline 54 1,1,2-Trichloroethane & n.a. & n.a. & n.a. & n.a. & n.a. & n.a. & n.a. & n.d. & n.d. \\
\hline 55 Trichloroethylene & 0.13 & 0.13 & 0.36 & 0.36 & 0.36 & 0.094 & 0.10 & 0.449 & 0.47 \\
\hline 56 CFC11 & 0.34 & 0.37 & 0.60 & 0.60 & 0.61 & 0.36 & 0.36 & 0.30 & 0.32 \\
\hline 57 Chloroform & 0.12 & 0.13 & 0.36 & 0.36 & 0.36 & 0.085 & 0.086 & 0.085 & 0.088 \\
\hline 58 CFC113 & 0.12 & 0.14 & 0.14 & 0.14 & 0.13 & 0.10 & 0.11 & 0.11 & 0.11 \\
\hline 59 1,2,4-Trimethylbenzene & 0.55 & 0.58 & 0.69 & 0.64 & 0.66 & 0.62 & 0.64 & 0.89 & 0.88 \\
\hline $601,3,5$-Trimethylbenzene & 0.12 & 0.09 & 0.12 & 0.12 & 0.11 & 0.17 & 0.17 & 0.26 & 0.25 \\
\hline 61 Toluene & 8.0 & 8.8 & 9.1 & 9.3 & 10 & 2.6 & 2.6 & 8.7 & 8.6 \\
\hline 62 Vinyl acetate & n.a. & n.a. & n.a. & n.a. & n.a. & 0.008 & 0.009 & 0.013 & 0.014 \\
\hline 63 o-Xylene & 0.56 & 0.59 & 0.77 & 0.77 & 0.79 & 0.49 & 0.55 & 0.71 & 0.74 \\
\hline $64 \mathrm{~m}-, \mathrm{p}-\mathrm{Xylene}$ & 0.76 & 0.79 & 0.97 & 0.97 & 1.0 & 0.64 & 0.70 & 1.0 & 1.0 \\
\hline
\end{tabular}

Underline means the value varied over $20 \%$ after storage.

The compounds of bold-face mean which were stable in the canister.

All samples were obtained in Kanagawa ,Hiratsuka-city(industrial area) for $24 \mathrm{~h}$.

n.a.:not analyzed n.d.:not detected 


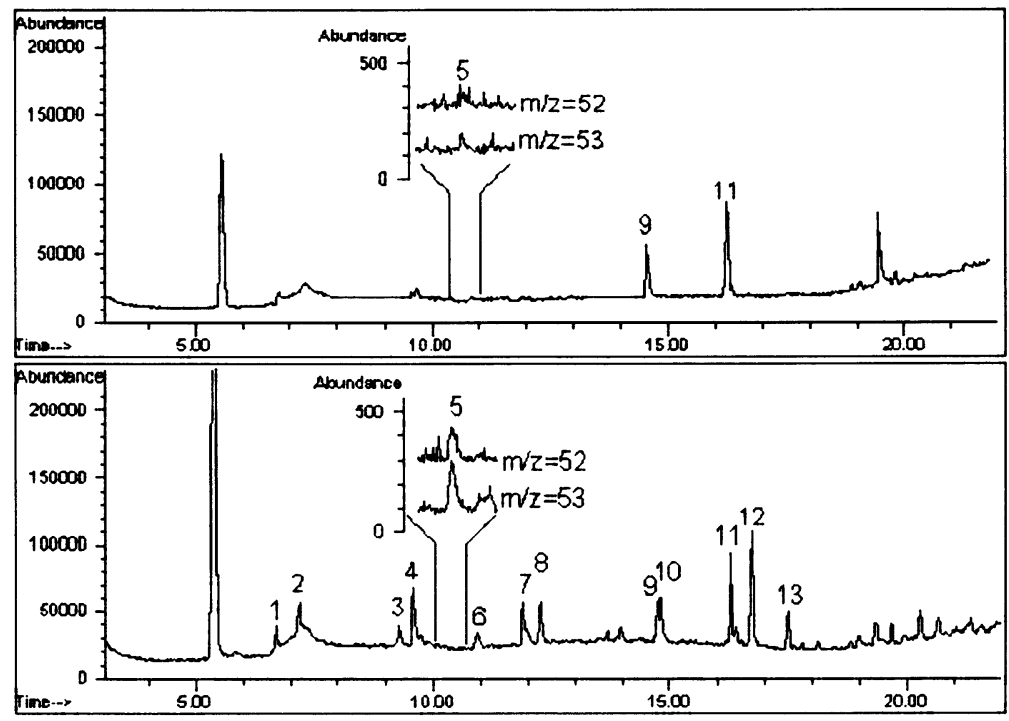

Fig. 1 TIC chromatograms of aldehydes etc. occurred in canister. After cleaning, the canister was evacuated and compressed to $10 \mathrm{psig}$ with humidified nitrogen. Upper chromatogram was analyzed on the day, lower was stored at room temperature and analyzed again after 42 days.

1: isobutene, 2: acetaldehyde, 3: propanal, 4: acetone, 5: acrylonitrile, 6: iso-butanal, 7: $n$-butanal, 8 : methylethylketone, 9: trioxane, 10: $n$-pentanal, 11: toluene $d 8$ (I.S.), 12: siloxane compound, 13: $n$-hexanal

$\left(0.09 \mu \mathrm{g} / \mathrm{m}^{3}\right)$ の増加, 1,3-ブタジエンは Silico 缶で最大 $0.03 \mathrm{ppbv}\left(0.07 \mu \mathrm{g} / \mathrm{m}^{3}\right)$ の減少を示した。アクリロニト リル，1,3-ブタジエンに大気環境基準はないが, 目標 定量下限值はアクリロニトリル $0.1 \mu \mathrm{g} / \mathrm{m}^{3}, 1,3-$ ブタジ エン $0.04 \mu \mathrm{g} / \mathrm{m}^{3}$ である。神奈川県内の1999年環境モニ夕 リング調査結果によるとアクリロニトリルの検出範囲は 定量下限值以下 $\sim 0.19 \mu \mathrm{g} / \mathrm{m}^{3}, 1,3-$ ブタジエンの検出範 囲は0.06〜0. $60 \mu \mathrm{g} / \mathrm{m}^{3}$ であり，0.07〜0.09 $\mu \mathrm{g} / \mathrm{m}^{3}$ 相当の 変動は精度管理上許容できない可能性が高い。保存する ことによって定量值が変化する可能性があることがわ かったので，定量分析は採取後速やかに実施する必要が ある。この他の 7 物質に関しては保存期間が長くなって も安定であった。

\section{4. まとめ}

キャニスターに採取した環境大気試料の精度よい定量 分析を実施するために，保存安定性を中心に検討を行っ た。1）一定濃度の標準物質を環境試料に添加する保存 安定性試験では，実施日によって一部物質に減衰傾向が 見られる場合と良好な保存安定性を示す場合があった。 キャニスターの個体差に加えて, 環境大気の共存成分が 試料保存性に影響を与え，その程度は試料の組成によっ て変動すると考えられた。そのためキャニスターに採取 した大気試料中化学物質は, 保存安定性が良好でない可 能性があるものとして取り扱う必要がある。2）実際の
環境大気試料の保存安定性は, 実試料より高い濃度の標 準物質添加実験とは違い増加傾向を示す物質があった。 濃度の上昇分は多くの場合 $0.04 \mathrm{ppbv}$ 以下であったため, 標準物質を0.4 2 ppbv 相当添加した保存安定性試験で は判別できなかったものと思われる。低濃度の環境大気 中化学物質をキャニスターで採取，分析する場合は実試 料での保存安定性を確認する必要があると考えられ た。3）キャニスター内でアルデヒド類など極性物質の 濃度が上昇する現象は，キャニスターの種類によらず広 く観察された。現状のキャニスターと洗浄方法で環境大 気中のアルデヒド類を測定するのは極めて困難であると いえる。4）キャニスターで測定する環境モニタリング 対象 9 物質のうち, 塩化ビニル, クロロホルム, 1,2ジクロロエタン， ジクロロメタン，ベンゼン，トリクロ ロエチレン，テトラクロロエチレンについては，保存安 定性は良好であった。保存期間が長くなるとアクリロニ トリルは過大に，1,3-ブタジエンは過小に評価される 可能性がある。環境試料及び標準物質を添加した環境試 料の保存性検討結果から, 極微量の極性物質の定量分析 は試料採取後 1 週間程度以内に実施する必要があると考 えられた。5）キャニスターに採取した試料の定量分析 はできるだけ速やかに行う必要があるが，フ、ロン類など 低沸点の無極性物質を中心とする28物質については，す べての実験で良好な保存安定性を示したので，1ケ月程 度の保存は問題ないと考えられる。このような物質の環 
境大気中濃度の測定には，キャニスター-GC/MS は極め て有効な方法である。

\section{要 約}

キャニスター中の環境大気試料の保存性を評価するた めに, 環境大気試料に添加した64物質と, 無添加の環境 大気試料から検出された 43 物質の保存安定性を検討し た。フロン類など低沸点の無極性物質を中心に28物質は 1 ケ月以上後も安定に保存されていた。キャニスター内 にアルデヒド類が残留し，保存すると濃度が上昇する現 象は Silico 缶, SUMMA 缶ともに観察された。同様の現 象がアクリロニトリルにも見られた。内部に残留してい る極性物質等が気相中に移行したと考えられる。キャニ スターで測定する環境モニタリング対象 9 物質のうち, 保存期間が長くなるとアクリロニトリルは過大に，1,3ブタジエンは過小に評価される可能性がある。

\section{文 献}

1）環境庁大気保全局大気規制課：有害大気污染物質測 定方法マニュアル（1997）

2）長谷川敦子：キャニスター-GC/MSによる大気中揮 発性有機化合物測定，環境と測定技術，25，53-56 (1998)

3) Daughtrey, E.H., Oliver, K.D., Adams, J.R., Kronmiller, K.G. and Lonneman, W.A.: Stringent comparison of sampling and analysis methods for VOCs in ambient air. PB Reports, PB-2000-100892 (1999)

4）赤松哲也, 佐藤慎二, 情野正道, 玉川勝美, 堀 昌善: 揮発性有機化合物の分析 キャニスター捕集 GC/MS 法と固体吸着 GC-ECD, FID 法との比較, 仙台市衛生研究所報，27，152-154（1998）

5）村山 等, 向井博之，森山 登：キャニスターを用 いた大気中揮発性有機化合物の測定における減圧採 取法と加圧採取法の比較, 環境化学, 10, 27-34 (2000)

6）反町潤, 金子正史, 南 直樹, 田辺広和：キャ二 スターを用いた大気中揮発性有機化合物分析法の検
討, 新潟県衛生公害研究所年報, 12，109-113（1997）

7）落合伸夫, 神田広興, 山下 暁, 代島茂樹 : キャニ スターを用いた大気中揮発性有機化合物の測定, 大 気環境学会年会講演要旨集，36，421（1995）

8）星 純也，泉川碩雄：容器採取一ガスクロマトグ ラフ質量分析法における揮発性有機化合物の測定精 度の検証, 東京都環境科学研究所年報, 1998，2834 (1998)

9) Kelly, T.J. and Holden, M.W.: Applicability of canisters for sample storage in the determination of hazardous air pollutants. Atmos. Environ., 29, 25952608 (1995)

10）落合伸夫, 辻 明, 瀧川義澄, 代島茂樹: 大気中 VOCs のキャニスター内での保存性についての検 討, 大気環境学会年会講演要旨集，38，411（1997）

11）佐藤啓市, 今村清, 田辺潔, 竹中規訓, 板 東 博, 前田泰昭：キャニスター法による有害污染 物 質の保存と定量, 環境化学討論会講演要旨集,

9, 510 (2000)

12) Kelly, T.J., Callahan, P.J., Pleil, J.D. and Evans, G.F.: Method developement and field measurements for poler volatile organic compounds in ambient air. Environ.Sci.Technol., 27, 1146-1153 (1993)

13) Brymer, D.A., Ogle, L.D., Jones, C.J. and Lewis, D.L: Viability of using SUMMA polished canisters for the collection and storage of parts per billion by volume level volatile organics. Environ. Sci. Technol., 30, 188-195 (1996)

14) Hasegawa, A.: Measurement of ethylene oxide in the atmosphere. J. Environ, Chem., 11, 11-15 (2001)

15) Yokohata, A., Makide, Y. and Tominaga T.: A new calibration method for the measurement of $\mathrm{CCl}_{4}$ concentration at $10^{-10} \mathrm{v} / \mathrm{v}$ level and the behavior of $\mathrm{CCl}_{4}$ in the atmosphere. Bull. Chem. Soc. Jpn., 58, 1308-1314 (1985)

16）今村清: 平成10年度化学物質分析法開発調査報告書 （その 1), pp178-193 (1999) 